\title{
Differentiated Instruction in Education
}

Dr. D. Sumathi Desinguraj, (Author) Assistant Professor,

School of Education, Tamil Nadu Open University, Saidapet, Chennai

Mrs. J. Shyla Gnanam, (Co-Author) Research Scholar,

School of Education, Tamil Nadu Open University, Saidapet, Chennai

Electronic version

URL: http://www.researchambition.com

DOI: https://doi.org/10.53724/ambition/v5n4.04

ISSN: 2456-0146

Vol. 5, Issue-IV, February 2021

Page No. 11-14

Publisher

Welfare Universe

email: publish2017@gmail.com

CResearch Ambition: An International Multidisciplinary e-Journal 2021. This Open Access article is published under a Creative Commons Attribution Non-Commercial 4.0 International License https://creativecommons.org/licenses/by-nc/4.0/, which permits non-commercial reuse, distribution, and reproduction in any medium, provided the original work is properly cited. For citation use the DOI. For commercial re-use, please contact editor email:- publish2017@ gmail.com By accessing the work you hereby accept the Terms. Non-commercial uses of the work are permitted without any further permission from Research Ambition: An International Multidisciplinary eJournal provided the work is properly attributed. 


\title{
DIFFERENTIATED INSTRUCTIONIN EDUCATON
}

\author{
${ }^{*}$ Dr. D. Sumathi Desinguraj \\ ${ }^{* *}$ Mrs. J. Shyla Gnanam Ebenezer
}

\begin{abstract}
:
\end{abstract}
Differentiated instruction is a way of planning and giving learning experiences according to the individual differences of the learners. Learners differ in their prior educational experiences, knowledge, interests, learning styles, personal experiences, readiness levels, motivation levels, and in their aptitudes. Traditional teaching methods do not address the student diversity in the classroom. So educators differentiate instructions in such a way that students of different grade levels grasp the concepts and exhibit mastery in the learned concepts. Students are provided with multiple opportunities and options for taking in and making sense of the information they receive. In this article some of the advantages or merits of differentiated instructions are discussed.

Key Word: Differentiated instruction: Teaching the students according to the individual differences.

\section{Introduction:}

Differentiated instruction is a teacher mind-set that all learners respond to instruction differently in their own way. Therefore, a one-size-fits- all mentality limits student opportunity to benefit from the instructional method applied in the classrooms. Teachers who utilize differentiated instruction take into consideration multiple aspects of learners to best meet their educational needs. Three diagnostic formative components are utilized to best understand personal characteristics of students and their academic skills: readiness, interest, and learning profile (Tomlinson, 2001).

A differentiated teacher plans the instruction based on individual students, not on a preplanned fixed curriculum. The teachers should accept that students differ from many perspectives, so as to prepare and design curriculums according to the students' interests, and abilities using various channels of presenting the lessons and with varied complexity. Acknowledging the importance of differentiated instruction in today's diverse classrooms, the current study aimed at investigating the efficacy of the approach on students at higher secondary level.

\footnotetext{
* (Author) Assistant Professor, School of Education, Tamil Nadu Open University, Saidapet, Chennai-15.

** (Co-Author) Research Scholar, School of Education,Tamil Nadu Open University, Saidapet, Chennai 15. 


\section{Working Together:}

All the students get a chance to participate in the learning activity. Teachers and students work with each other. Leaners get a chance to clarify their doubts and learning by doing is enhanced. Working together gives a chance for students to engage themselves continuously and strength and weakness of students get balanced which in turn improves their learning outcome.

\section{Proper Usage of Time and Space:}

Wise usage of time and space are planned by the teacher and the entire productive activities takes place by the coordination of the teacher. Students may take varying length of time to complete the task. Quality in terms of learning outcomes are insisted rather than quantity.

\section{Working Together and Flexible Grouping:}

All the students get a chance to participate in the learning activity. Teachers and students work with each other. Leaners get a chance to clarify their doubts and learning by doing is enhanced. Working together gives a chance for students to engage themselves continuously and strength and weakness of students get balanced which in turn improves their learning outcome. Each student can have a learning buddy with whom they feel comfortable and complete their learning activities.

Flexible grouping includes whole class participation in the learning activities, working in pairs, student selected group activities, random group project and teacher selected group work. When children teach each other, learning takes place effectively. Re teaching an idea or skill for struggling learners or to extend the higher order thinking or skills of advanced learners are enhanced. The advantage of flexible grouping is that it promotes communication and it builds understanding from various perspectives which intun builds the background knowledge and brings success in the workforce.

\section{Proactive Planning:}

It is an important aspect on the part of the instructor which is done by pre assessing the students for their learning preferences, readiness levels, and interests. Instructions are planned for a mix of whole class, group, and independent learning. Forethought, planning and advance consideration of the student's social, emotional and cognitive learning are observed. It helps in minimizing disruption, distraction and interference with students learning.

\section{Meeting The Needs Of Students Diversity:}

Before planning the educational objectives, contents and methodologies individual differences are kept in mind and studied. Differentiating the instruction according to the learning styles of students helps in achievement of students to the fullest of their capacity. Manipulatives are offered for hands on experiences. 


\section{Teaching According To The Intelligence Strengths:}

According to Howard Gardner there are nine intelligences. They are linguistic, logicalmathematical, spatial, bodily-kinaesthetic, musical, interpersonal, intrapersonal, naturalistic and existential. Teachers have to identify how each student will learn best. After identifying the intelligence strengths of each student, the educator started planning and educating them. Learning activities can be planned using variety of materials and methods.

\section{Categorized Activities}

Using blooms taxonomy, teachers can categorize activities and questions by the level of complexity so that children can solve problems in their own space. Concepts at the higher level of Blooms taxonomy should include active and collaborative learning activities like discussions, role playing, cooperative games etc.

\section{Meaningful Tasks And Tiering Activities:}

Students are encouraged to produce their own assignments that contain the required output. Activities, assignments and projects are always planned for a heterogeneous student groups. Students are engaged by offering choices and there are fewer discipline problems in the classrooms where teachers provide differentiated instructions. Activities with a clear purpose and learning objectives are included. Activities with understandable directions and a plan of assessing the objectives are given. Student's readiness to participate and the way of eliciting feedback from students from their experiences are well planned.

\section{Multiple Options And More Than One Method:}

Information is given to students using more than one method and assessments also done using more than one method. The learning outcome of students are not only assessed using paper and pencil test but also using projects and presentations. Using a standardised test is not a fair way to measure student's growth in knowledge. Differentiated instruction offers students with many options to choose assignments or projects based on their intelligence strengths.

\section{Hooking The Whole Range Of Learners:}

The most effective teachers do whatever it takes to hook the whole range of learners in the classroom and get each students attention to make learning a most effective one. The teacher create a reasonable range of approaches like rethinking, trial, reflection, and adjustment in the classroom practices. Teachers make sure that the right student get the right learning task at the right time.

\section{Ongoing Assessment:}

Diagnostic tests are kept often so that remedial measures are taken to recover the mistakes in the learning process. Pre assessment, formative assessment and summative assessments are part and parcel 
of differentiated instruction. Assessment helps the instructor map the next steps for varied students. Assessments are focused on personal growth rather than on peer competition.

\section{ICT As A Methodology In Differentiation:}

Information and communication technology facilitates self-paced learning and provides choice for the learner. It provides information in a multisensory way via visual, aural, diagrammatic, pictorial, text style etc. It provides opportunities for students to acquire and process information effectively and develop products.

\section{Conclusion:}

The effectiveness of differentiated instructional approach depends upon a positive learning environments, high quality curriculum, a flexible classroom management and a multiple way of assessment patterns. It emphasise a balance between the individual students with the course content. Differentiation is all about behind the scenes planning that goes into effective lesson design for diverse classrooms.

Educational planners should build a vision for differentiating instruction and develop educator's skills to apply this. Educators must be provided with incentives to learn and implement it. Instructional needs of today's diverse array of learners must be met so that learners will be able to deal with new situations. Time, resources, and complexity are the three factors that have to be planned well to give a perfect differentiation in the classroom. Developing, expanding and sustaining a differentiated instruction in the classroom is the need of an hour.

\section{References:}

1. Galbraith, J. \& Delisle, J. (2015): When Gifted Kids Don't Have All the Answers. Minneapolis, MN: Free Spirit Publishing.

2. Ie May Freeman, Ed.D. (2015): Differentiated Instruction and Its Impact on Diverse Learners. Journal of Education and Human Development December 2015, Vol. 4, No. 4, pp. 147-154, ISSN: 2334-296X (Print), 23342978 (Online)

3. Sarra' Majdy El Masry (2017): A thesis submitted in partial fulfillment of the requirements for the degree of Master of Curricula and Teaching Methods September/2017.

4. Tomlinson, C. A. (2001). How to differentiate instruction in mixed ability classrooms ( $2^{\text {nd }}$ ed). Alexandria, VA: Association for Supervision and Curriculum Development.

5. Ismajli, H., \& Imami-Morina, I. (2018): Differentiated Instruction: Understanding and Applying Interactive Strategies to meet the needs of all the Students. International Journal of Instruction, 11(3), 207-218. https://doi.org/10.12973/iji.2018.11315a

\footnotetext{
$* * * * * * * * * * * * * * * * * * * * * * * * * * * *$
} 